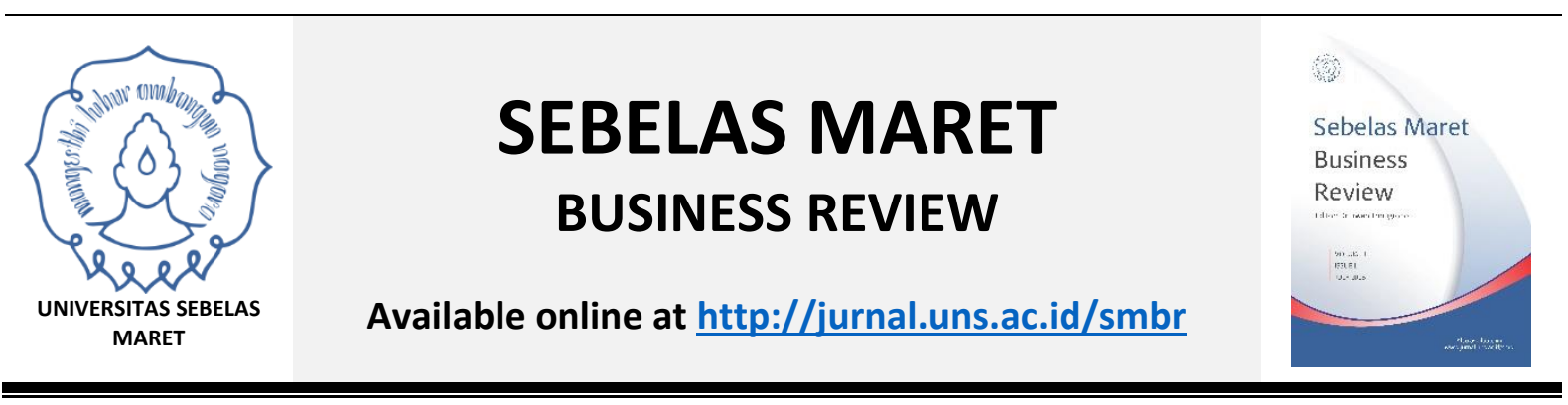

\title{
The Impact of World Food Price Fluctuation Towards Indonesian Macroeconomics
}

\author{
Jami Ilmia, Regina Niken W. *, Agus Luthfi
}

Jember University, Jember, East Java, Indonesia

*Email: reginanikenw@gmail.com

\begin{tabular}{ll} 
ARTICLE INFO & ABSTRACT \\
\hline Article History: & $\begin{array}{l}\text { Stability of price is a crucial factor for export and import } \\
\text { activities, especially food commodities. Indonesia with the } \\
\text { characteristics of a small open economy are vulnerable to } \\
\text { external price shock as the implication of economic } \\
\text { geceived 30 August } \\
2017\end{array}$ \\
$\begin{array}{l}\text { geceived in Revised } \\
\text { Form }\end{array}$ & $\begin{array}{l}\text { for designing risk mitigation to minimize the effects of } \\
\text { shocks to macroeconomic variables. The purpose of this } \\
\text { Accepted 16 September } \\
2017\end{array}$ \\
$\begin{array}{l}\text { Available online 13 } \\
\text { September 2017 }\end{array}$ & $\begin{array}{l}\text { Vector Auto-Regression (VAR) methods. The sensitivity of } \\
\text { impulse response estimation and variance decomposition } \\
\text { which outlines how large and how the effect of the food } \\
\text { price shock. Impulse response analysis shows shocks on } \\
\text { global food price got the response by fastest and the most } \\
\text { powerful by inflation. While the description of variance } \\
\text { decomposition, variation described by economic } \\
\text { growth. The results show that the global food price affects }\end{array}$ \\
\hline Keywords: & $\begin{array}{l}\text { economic growth that is transmitted through inflation. } \\
\text { Food price shock, }\end{array}$ \\
Macroeconomy, &
\end{tabular}

\section{INTRODUCTION}

Indonesia's characteristic as the small open economy in an increasingly integrated global economy is highly vulnerable to be influenced by external shocks, such as world food prices. Developing countries are characterized by a large domestic food sector; based on the consumption pattern, people use most of their income for food expenditure. Ikhwan (2014) states that based on consumption pattern of Indonesian 
people, they spend nearly 50 percent on food expenditure. An increasingly open world food trade system has an impact on the difficulty of controlling domestic food products due to the transmission of international price fluctuations. The high food prices are causing various economic problems both from the macro side and from the macro side. Thus, it is important to analyze the effects of world food price shocks on small open economies such as Indonesia. Some empirical studies explain that an increase in international prices can affect domestic prices and lead to an acceleration of inflation. Based on studies conducted Headey and Fan (2008), Abott et al. (2009), Galesi and Lombardi (2009), Hakro and Omezzine (2010) shows that food prices are related to macroeconomic variables such as inflation, output, interest rates, exchange rates and trade. On the other hand, food price shocks can slow economic growth. Khaliq's view (2015), anticipating the negative impact of external shocks requires an effective and efficient macro policy.

FAO (2011) states that risks and uncertainties lead to higher volatility. Understanding of external price fluctuations substantially contributes to the mitigation of shock risks to a country's economy. The pattern of rising world food prices followed by rising domestic food prices will put pressure on the stability of the economy. In developing countries, rising food prices can increase inflation because the average food consumption occupies the largest portion of the level of public consumption. The turbulence of vulnerable economic activity creates a prominent contribution to rule making regulations that lead to economic stability. Siregar et al. (2006) states that economic stability can be seen from the impact of shocks of a variable on other macroeconomic variables.

Rising food prices are a burden for the sustainability of the economy in developing countries, including Indonesia. As Bourdon exposes (2011) that unstable food prices are a risk to developing countries. In macro terms, food price fluctuations will affect inflation and GDP (Hardjanto, 2014). This research aim to answer 'How world food price turmoil on Indonesia's macroeconomics?' This research uses vector autoregression approach (VAR). Tool of analysis used in this research is accounting innovation consisting of impulse function and variance decomposition; generally describes how and how big the effect of shock to other variables on the VAR equation that formed.

\section{LITERATUR REVIEW}

The volatility of global food prices occurred during the international food crisis in 2007 to 2010 (Timmer, 2011; Jayasuriya, et al., 2012; Minot, 2012; Hardjanto, 2014). Global commodity prices increased and peaked in 2007, then declined during the financial crisis and again increased sharply in 2011 (Braun and Tadesse, 2012).The volatility of food prices or commodities traded are linked to macroeconomic performance. Several studies have been conducted to examine the relevancy between volatility and macroeconomic performance and economic growth as in Kargbo (2005), Apergis and Rezitis (2011), Choi and Kim (2012) studies. Furthermore, macroeconomic performance can be understood using inflation approach and economic growth approach.

The increasingly open of world food trade system has cause some difficulty to control the domestic food products, due the transmission of the international price fluctuations. Based on the description of Tomik and Robinson (1990 in the trade ministry, 2015), food prices are determined by both local and imported supplies, demand, food price situations in international markets, and public expectations. Research on 
fluctuations in the impact of world food prices has made some previous researchers. Several studies have focused on the increase in food prices and its linkage to the macroeconomic (Headey and Fan, 2008; Abott et al., 2009; Galesi and Lombardi, 2009). The study results prove that food price shocks are transmitted to macroeconomic variables such as inflation, output, interest rates, exchange rates and trade. One of the models using IS-MP-PC is Shobande and Alimi (2015). The Shobande and Alimi research aims to stabilize the macro economy in Nigeria by including a net export variable to analyze exogenous shocks. In addition, the study explains the difference of the IS-LM policy hypothesis using Money Supply (JUB) as an exogenous variable with an IS-MP model that considers monetary policy reactions to stabilize macroeconomics. Shobande and Alimi found that Nigerian output was positively influenced by net exports.

Some literature reveals that food prices play a role in slowing world economic growth (Khaliq, 2015). Empirical research conducted by Khan and Ahmed (2011) mentions that the rising of global food prices could reduce demand for food exports, ultimately affecting the decline in net exports that are part of the national income. Mankiw in his book mentioned net exports are the value of goods and services exported to other countries minus the value of goods and services imported from other countries, since imported goods and services are not part of the output of a country (Mankiw, 2006: 114).

In addition, Alom (2011) examines the economic impact of oil price shocks and food prices in several Asian countries. In the study, food price shocks encouraged real exchange rate depreciation in almost all countries except Singapore. Based on research (Alom, 2011: Khan, 2011; Khaliq, 2015) the real exchange rate becomes depressed due to excessive import bill resulting from rising food prices so that demand for dollars increases. Meanwhile, (Headey and Fan, 2008; Abott et al., 2009) conducted an in-depth study of the crises caused by world food prices. They attained the fact that there is a food price transmission mechanism on the weakening of the exchange rate against the dollar.

Galesi and Lombardi (2009) identify that oil shocks and food prices have different effects, inflation of oil prices largely affects developed countries while food prices only affect developing countries. In most developed countries, food expenditure contributes for a relatively small share of household budgets, while in developing and poor countries, most household expenditures are used for food purposes (Apergis and Rezitis, 2011). Based on the FAO (2009) report, food prices are rigid, so low-income countries should bear the consequences of high food prices. Supported by the statement of Jongwanich and Park (2011) that rising food prices have a considerable impact on overall consumer prices because food has a substantial share of consumption in developing countries.

Theoretically, the impact of food price shocks can lead to an increase in inflation especially in food importing countries. Unlike oils that are included in production inputs, food products are consumed directly by consumers, so the rise in food prices has a more direct effect on inflation. The inflation rate of food groups on inflation will be greater due to the high food expenditures made by most people. Thus, the linkage between the aspects of food prices and inflation is an important issue to be studied more deeply. Based on the analysis conducted Carton et al. (2013) uncertainty between core inflation and food inflation can lead to poorly affected policies. This is evidenced by Choo study in 2015 which found that demand shocks Investment Saving (IS) curve shifts to the right to increase the interest and output, and rising prices lead to inflation and then responded monetary policy by lowering interest rates, but inflation is rising. 


\section{METHODOLOGY}

\section{Vector Auto-Regretion model}

VAR was first introduced by C. A. Sims (1972) as thought of Granger (1969) which was then widely used in econometric studies. VAR is also one of the dynamic linear model (MLD) that is being used in the application of forecasting variables (especially) economics in the long term and medium-long term. As part of econometrics, VAR is one of the discussion in multivariate time series. Gujarati (1995), states there are several advantages of VAR analysis, one of which is a simple model, so researchers do not need to determine which endogenous variables and which include exogenous variables because all variables in VAR are endogenous. Individually, the coefficients in VAR models are difficult to interpret, experts econometric analysis Responsse Imlulse Function (IRF). IRF is used to determine the effect of a shock from an endogenous variable to another variable in the VAR systems due to disturbances (shocks) or a change in the disturbance variable (e). Besides impulse response, the VAR model also provides an analysis of forecast error variance decomposition is often called the variance decomposition (VD). VD is useful for predicting the percentage contribution of each variable variance due to changes in certain variables in the VAR system (Widarjono, 2013).

\section{Specification of Research Model}

Referring to the IS-MP-PC (Romer, 2000), can be written sungsi IS, MP (Monetary policy), and PC (Phillips Curve) as follows:

$$
\begin{aligned}
& Y=E(Y, r, G, T, \varepsilon) \\
& r_{t}=r_{t}+\alpha\left(\pi_{t}-\pi^{e}\right)+\beta\left(y_{t}-y^{e}\right) \\
& \pi_{t}=\pi^{e}+\beta\left(y_{t}-y^{e}\right)+\epsilon_{t}^{\pi}
\end{aligned}
$$

Simplified into function:

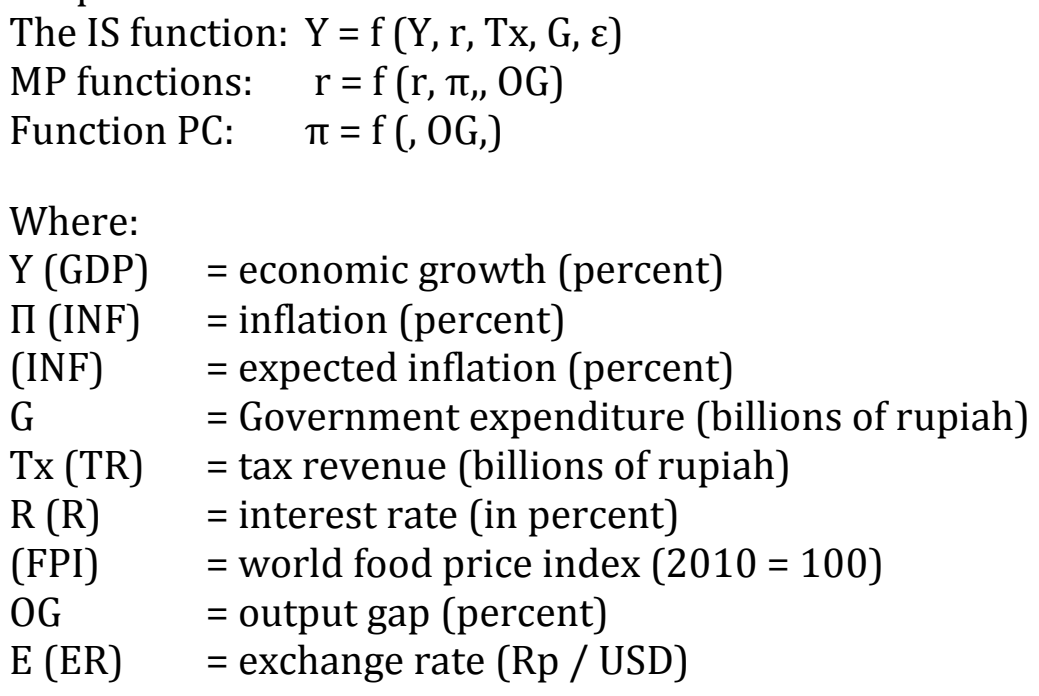

Based on the equation function of the three models, the VAR model equation to see the impact of food price shocks on the economy in this study is as follows:

$$
\begin{aligned}
\operatorname{PDB}_{\mathrm{t}}= & \beta_{0}+\beta_{1} \mathrm{INF}_{\mathrm{t}-1}+\beta_{2} \mathrm{EINF}_{\mathrm{t}-1}+\beta_{3} \mathrm{R}_{\mathrm{t}-1}+\beta_{4} \mathrm{G}_{\mathrm{t}-1}+\beta_{5} \mathrm{TR}_{\mathrm{t}-1}+\beta_{6} \mathrm{ER}_{\mathrm{t}-1}+ \\
& \beta_{7} \mathrm{OG}_{\mathrm{t}-1}+\beta_{8} \mathrm{FPI}_{\mathrm{t}-1}+\mathrm{e}_{3}
\end{aligned}
$$


The analysis in this study uses annual data from 1984-2016. food prices datas are obtained from the FAO, the rate datas and expenditures are derived from Bank Indonesia, the exchange rates, inflation, inflation expectations and economic growth datas are obtained from the World Bank, the tax data obtained from the Badan Pusat Statistik (BPS) and the Ministry of Finance, and the data the output gap is obtained using the HodrickPrescott (HP) filter from GDP data are sourced from the Ministry of Finance.

\section{RESULT AND DISCUSSION}

\section{Innovation: Impulse Response}

Response of PDB to Cholesky One S.D. FPI Innovation

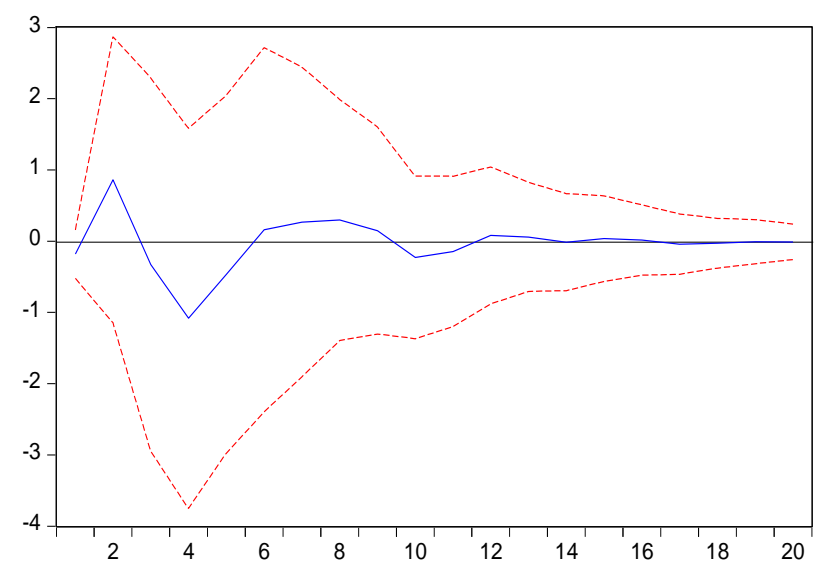

Response of $\mathrm{R}$ to Cholesky One S.D. FPI Innovation

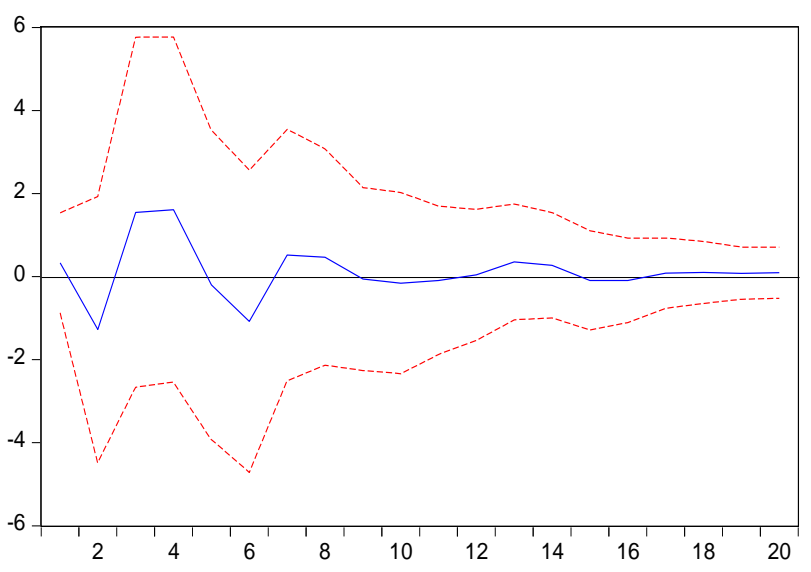



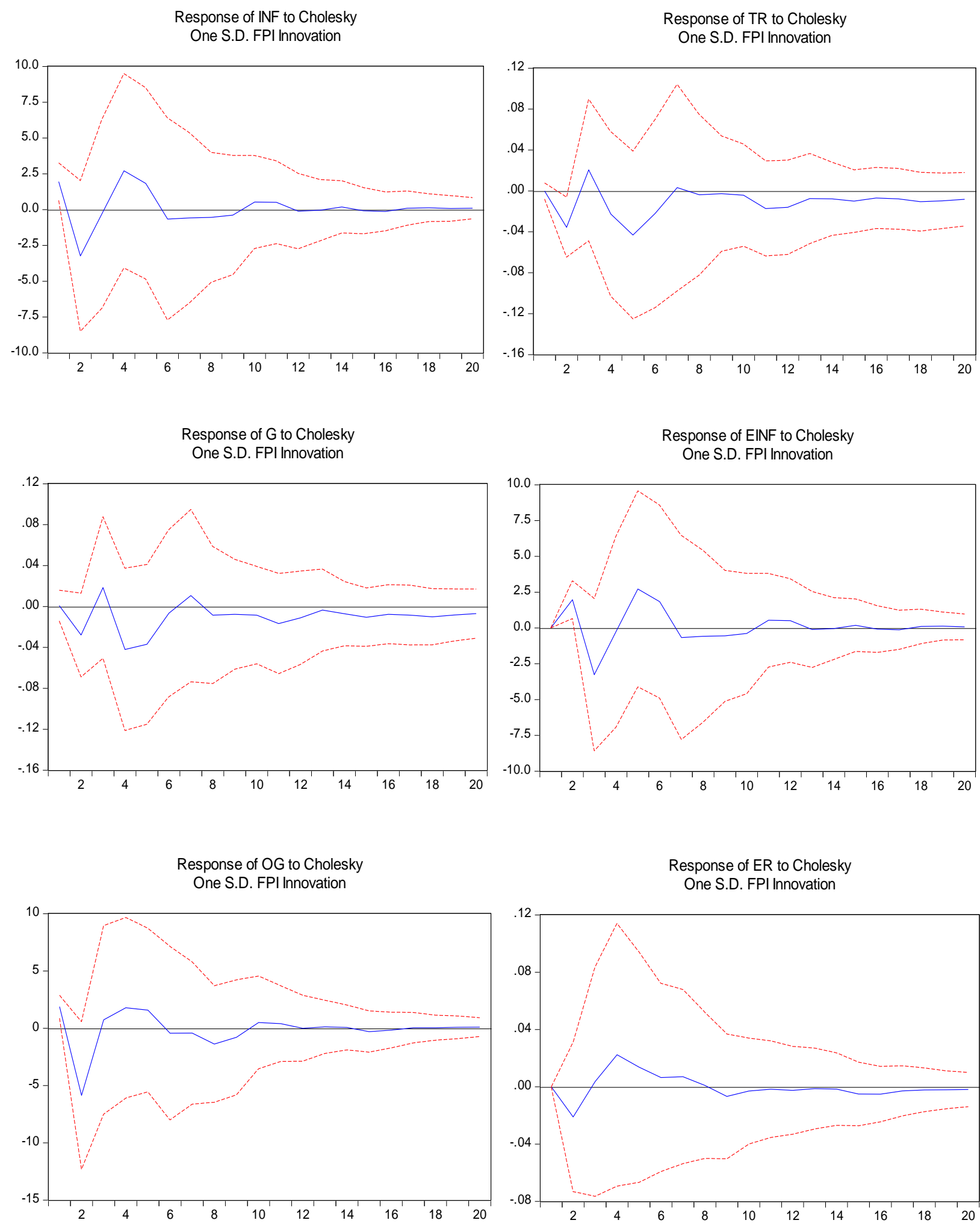

The rise in food prices reflects higher inflation, based on Jalil and Zea (2011) exposure, the rise in international food prices leads to an increase in imported food prices, so that people turn to local products and there is an increase in demand that adds to the inflation pressure of goods groups. Inflation is one of the variables that can show macroeconomic performance because it is an economic problem that can affect the real sector and monetary sector (Hardjanto, 2014). Effect of food price shock on inflation 
based on impulse response showed a positive relationship cumulatively, so that the increase in food prices affect the increase in inflation. In quantitative terms, the results of variance decomposition outlines an explanation of changes in inflation are affected by the exchange rate are dominant in the short term. These results indicate that the transfer price over the pass trough effect on inflation in response to price changes. These results are validates by Milasari (2010), that the exchange rate has an impact on inflation through imports of consumer goods (foodstuffs) included in the first direct passthrough because the price of food imports that may directly affect the selling price in the country.

According to Taylor (2000), the inflation condition of a country is very influential on the size of how much influence the exchange rate changes to the price level. Taylor said the effect of exchange rate on domestic price changes is smaller in countries with relatively low inflation rate compared to countries with high inflation rate. Indonesia's inflation data shows that in the period of 33 years (1984-2016) showed a fluctuating trend. The highest inflationary rise in 1998 indicated a weakening of the economic defense system against external shocks. Meanwhile in the same year, the exchange rate also experienced a very strong depreciation.

Based on the results of variance decomposition in inflation explained that changes in inflation are affected by exchange rates and expenditure. While the results of the estimation variance decomposition on the exchange rate is affected by the world food prices in the short term as well as long-term government spending. The results indicate that the exchange rate is explained by food prices while inflation is explained by exchange rates. So that the effect of the global food price shocks are transmitted through the exchange rate to inflation, according to Milasari (2010), the coefficient of influence (pass through) the exchange rate of world commodity price shocks (food) is transmitted to domestic prices reflected by inflation.

The results of impulse responsse exchange rate stimulation on food prices showed a cumulative negative response. The negative response indicates that food price rising will strengthen rupiah value. The strengthen of rupiah will affect the decline in export and import performance will increase (Susanti, no year). Import influence is very important to the development of domestic prices. Based on several conducted studies, it stated that import prices has significant effect on domestic prices (Aziz, 2006: Chairina et al., 2014).

In the long run, inflation and the exchange rate are explained by the Government expenditure as a dominant variable affecting each variable based on the estimation variance decomposition. These results indicate that, in the long term, fiscal policy responses through changes in government spending. Fiscal policy has two priorities, the first of which is to overcome the budget deficit, and the second is to overcome macroeconomic stability related to employment, balance of payments, inflation rate, and economic growth (Tambunan, 2006). Based on the VAR estimate, food prices negatively affected significantly against the second leg. So it can be concluded that rising food prices can lead to a decrease in government budget for the next period. In line with the impulse response result that explains that government expenditure spending is responded negatively.

Government Expenditure is an autonomous aggregate expenditure component (G0), since national income is not a determining factor affecting government decisions in budgeting process. Government expenditure is included in the fiscal policy component that plays a role in overcoming the economic problems faced, where one of them is economic instability (Sukirno, 2003). The negative response shown in responsive 
impulses shows that the policy response to reduce the impact of food price shocks is a contractionary fiscal policy. The policy aims to reduce people's purchasing power and cope with inflation.

Tax revenues respond negatively to rising food prices due to impulse responses, so that rising world food prices could lead to a decrease in tax revenues. An external factor that can affect a country's tax revenue is inflation An external factor that can affect a country's tax revenue is inflation (Syahputra, 2006). Thus, an increase in international food prices, followed by rising domestic prices may lead to inflation and implies to the decline in tax revenues.Based on the tax revenue annual reports, there are revenue increases every year. This condition is influenced by government expenditure variable which also increases every year. On the other hand, the internal factor that may affect the tax revenue is the tax rate itself. (Syahputra, 2006).

In the event of external shocks as happened in 1998 and 2008, the surge in prices led to rise in inflation so that monetary policy responded by raising interest rates. Where, the rise in inflation will affect the increase in interest rates, while the decline in inflation will have an impact on the decline in interest rates. The role of monetary policy at the interest rate used as a monetary policy instrument is described in the Taylor Rule model. This model explains how much interest rates should be set so that inflation can be controlled and reach a predetermined target (within the framework of inflation targeting) (Murwani, 2007). In the determination of the interest rate, expectations also need to be taken into account in addition to other factors such as banking liquidity, inefficient banking management, and banking segmentation. (Nurdianti, without years). An increase in food prices will encourage an interest rate response to an increase in inflation expectations, so the monetary authority will increase interest rates. Yulius (2014) states, the focus of monetary policy is to maintain the commitment and ability of the central bank to influence inflation expectations and interest rates in the future.

The results show that the impulse response has accumulatively positive response. This indicates the rise in world food prices responded by rising interest rates. The highest increase in interest rates occurred in 1998 up to 38.44 percent. The increase was quite high from 20 percent in 1997. The increase in interest rates was made in an effort to suppress uncontrolled inflation with a very sharp increase from 6.23 percent to 58.93 percent. Then in 1999-2000, interest rates declined, but in 2001 again increased. In the case of price shocks in 2008, interest rates rose again. The tight money policy of raising interest rates with the aim of reducing inflation, but on the other hand this policy can affect the real sector performance associated with the development of the business world. Todaro (1998) argues that today, economic growth is a central topic in the life of the economy. Regarding economic activities in a country, economic growth is one of the main indicators in measuring the success of economic development. Economic growth fell sharply in 1998 to -13.13 percent. The decline is the lowest due to the global crisis and also the world food price shocks that cause the economic foundation to be weak. In 2009, the domestic economy again experienced a significant slowdown from the previous year by 6 percent to 4.6 percent. One of many factors that slowdown the economic is caused by the world food price shocks that affect on the contraction between the volume of import and export of world trade. The result of VAR describes estimation of economic growth, inflation is the most significant variable affecting with the regression coefficient. High inflation will have a negative impact on economic growth because the regression coefficient shows a negative sign. After inflation, inflation expectations also have a significant effect. The condition reflects that public expectations of rising inflation will increase consumption, so that when uncontrolled price conditions will cause 
economic growth to decrease. The response shown by the growth of food price shocks can be seen in the estimated impulse response cumulatively indicates a negative response. This means that rising world food prices will cause a decline in economic growth.

Meanwhile, the results of variance decomposition outlines that the world food price shocks give the largest contribution in explaining economic growth. Food price fluctuations affect domestic economic growth in terms of imports, especially food imports. Most of the international trade in agricultural commodities uses the dollar currency. Thus, exchange rates also play significant role in explaining economic growth. The exchange rate gives the second biggest influence after the food price and can explain the variation of economic growth..

Economic growth in crisis in 1998 reached its lowest point and negative value. Then gradually improved, until the food price shocks that happened in the year 2008 inhibit it growth again. The slowdown resulted in a significant decline in 2009 to 4.6 percent from the previous position in 2008 of 6.5 percent. The 2005-2016 economic growth is underpinned by household consumption with the largest expenditure contribution in GDP at an average of more than 50 percent annually. Increased demand for household consumption will encourage commodity production activities, thereby reducing the impact of price fluctuations.

\section{CONCLUSION}

Based on impulse response analysis, shocks to the global food price response gets most rapid and vigorous response inflation. Thus, it can be concluded that inflation is very vulnerable towards food price volatility. Meanwhile, inflation is a variable that can affect the movement of other variables in the economy so that the increase in inflation can have adverse effects.

The result of variance decomposition analysis shows that the biggest role of world food prices in explaining fluctuations in macroeconomic variables in Indonesia is on economic growth. Thus, it can be concluded that the world food price fluctuations affect Indonesia's economic growth through inflation. While in each variable, it can be found that in the long run (over 10 years period) the government expenditure variable dominates in explaining the change of each variable. Thus, to affect the impacts that occur as a result of food price shock using variables government spending. This can be explained by Keynesian thought that fiscal policy is the main tool of macroeconomic policy.

\section{REFERENCES}

Abbott, P.C., Hurt, C., and Tyner, WE 2011. What's Driving Food Prices in 2011? Farm Foundation

Alom, F. 2011. "Economic Effects of Oil and Food Price Shocks in Asia and the Pacific Countries: An Application of svar Model". In New Zealand Agricultural \& Resource Economics Society, August 2011

Apergis, N. and Rizitis, A. 2011. Food Price Volatility and Macroeconomic Factors: Evidence from GARCH and GARCH-X Estimates. Journal of Agricultural and Applied Economics, No. 43, 95-110

Bekaert, G., Cho, S., and Moreno, A. 2010. New Keynesian Macroeconomics and the Term Structure. Journal of Money, Credit, and Banking Vol. 42, No. 1 
Braun, JV 2008. High and Rising Food Prices. Journal of the International Food Policy Research Institute (IFPRI). May 6, 2008

Carton, B., Coulibaly, D., and Pourroy, M. 2013. Food Price Shock and Monetary Policy. University Paris 1 Panthénon-Sorbone-France, Novemver 24, 2013

Choo, JWM 2015. The Applicability of the IS-PC-MR model on the UK Economy During the Crisis. UCL Economics, March 2015

Galesi, A. \& Lombardi, MJ 2009. Inflation External shocks and International Linkages: A Global VAR Analysis. European Central Bank, WP. 1062

Gali, J. 2008. The Monetary Policy, Inflation, and the Business Cycle. United Kingdom: Princeton University Press

Harjdanto, A. 2014. Food Price Volatility and Its Influence on Indonesia Macroeconomic Indicators. Bogor Agricultural University - Bogor

Headey, D. and Fan, S. 2008. Anatomy of a Crisis: the causes and Consequences of surging Food Prices. Journal of Agricultural Economics 39 IFPRI, September, 28-2008, 375-391

Jalil, M. and Zea, ET 2011. Pass-through of International Food Prices to Domestic Inflation During and After the Great Recession: Evidence from a Set of Latin American Economies. Y Desarrollo Sosiedad, Primer semestre de 2011, PP. 135-179: ISSN 0120-3584

Jayasuriya, S., Mudbhary, P., and Broca, SS 2012. Food Price Spikes, Increasing Volatility and Global Economic Shochs: Coping with Challenges to Food Security in Asia: A Regional Comparative Study of the Experiences of Ten Asian Economies. Bangkok (TH): Food and Agricultural Organization (FAO) of the United Nations Regional Office for Asia and the Pacific (RAP)

Khan, MA and Ahmed, A. 2011. Macroeconomic Effects of Global Food and Oil Price Shocks to the Pakistan Economy: A Structural Vector Autoregressive (svar) Analysis. The Pakistan Development Review 50: 4 Part II, pp. 491-511

Khaliq, A. 2015. Oil Price Shocks Transmission Mechanism and the World Food Prices to the Indonesian Macro Economy: Approach Structural Vector Autoregressive (svar).Bunda Mulia bussines Management Journal, Vol. 11 No.2, September 2015

Mankiw, NG 2006. Macroeconomic sixth edition (translation). Jakarta: Erland

Minot, N. 2012. Food Price Volatility in Africa Has it Really Increased. International Food Policy Research (IFPR) Discussion Papers 01239

Murwani, S. 2007. Analysis of Monetary Policy Relation to Foreign Investment: Taylor Rule approach. Postgraduate Program of Diponegoro University-Semarang

Romer, D. 2006. Advanced Macroeconomics Third Edition. New York: The McGraw-Hill Companies, Inc.

Shobande, OA \& Alimi, OY 2015. "Exogenous Macroeconomic Variables and Nigerian Output: An Extension of the Taylor Rule and IS-MP-PC Model". In Developing Country Studies Vol.5, No. 17, 2015

Timmer, CP 2011. Managing Price Volatility: Approaches at the Global, National, and Household Levels. Stanford Symposium Series on Global Food Policy and Food Security in the 21st Century.

Widarjono, A. 2013. Econometrics: Introduction and Applications Fourth Edition. Yogyakarta: UPP STIM YKPN

Julius. 2014. Macroeconomic Period of the Crisis. Directorate of Macroeconomic Planning Bappenas, Edition 01 - May 2014. 